\title{
Evaluation and mapping of corrosion in a western USA underground metal mine - year one preliminary results
}

\author{
AJ Chambers National Institute for Occupational Safety and Health, USA \\ CB Sunderman National Institute for Occupational Safety and Health, USA \\ DJ Benton National Institute for Occupational Safety and Health, USA \\ JT Brennan National Institute for Occupational Safety and Health, USA \\ DT Orr Hecla Mining Company, USA
}

\begin{abstract}
Corrosion of ground support can lead to falls of ground, posing a significant risk to miner safety. To address this problem, the Spokane Mining Research Division of the National Institute for Occupational Safety and Health is investigating ground support corrosion at the Greens Creek mine, located near Juneau, Alaska, United States of America. Field and laboratory studies include surveys of weld-wire mesh corrosion, rock mass conductivity measurements, and sample analyses using a scanning electron microscope, energy dispersive spectrometry, and Fourier transform infrared spectrometry. Current field studies demonstrate a correlation of rock mass conductivity to the degree of weld-wire mesh corrosion and the relationship of ground conductivity surveys to support corrosion potential. Laboratory analyses of mine samples identify the presence of sulphate, which is a determinant for sulphate reducing bacteria activity. Identification of sulphate reducing bacteria (SRB) would provide evidence for microbial influenced corrosion in this mine. Ongoing research is evaluating methods of SRB inhibition. These results provide engineers with a means to map corrosion potential of the rock mass, and identify a number of paths for design of focused mitigation efforts for problem areas.
\end{abstract}

Keywords: corrosion, sulphate reducing bacteria (SRB), microbial influenced corrosion (MIC), resistivity, safety

\section{Introduction}

Controlling ground stability to protect miners from falls of ground is one of the oldest mining sciences, and considerable research has led to a variety of modern tools in use today. Increasingly higher-strength steel grades have been used to meet the increasingly demanding requirements placed on rockbolts in underground mines (Elias et al. 2013). However, the benefits of these higher-quality support elements can often be negated in highly corrosive mining environments. The National Institute for Occupational Safety and Health (NIOSH) Spokane Mining Research Division (SMRD) seeks to reduce the number of rockfall injuries and fatalities through research and collaborations with others who share this goal.

Accelerated corrosion has been occurring in some areas of Hecla Mining Company's Greens Creek mine. Two falls of ground occurred between April $2015\left(21.5 \mathrm{~m}^{3}\right)$ and March $2016\left(12.2 \mathrm{~m}^{3}\right)$. While these falls of ground were one half to one metre deep and did not injure any personnel, mine management recognises the high risk to miner safety and is responding by actively undertaking a ground support rehabilitation programme. These rehabilitation measures include the installation of galvanised bolts and mesh, as well as the installation of polymer-coated, corrosion-resistant bolts and mesh.

Following the first ground fall, the Hecla Mining Company initiated a cooperative research effort with SMRD to investigate the underlying mechanisms of ground support corrosion, identify the contributing factors, devise methods for assessing the extent of corrosion on ground support elements, and develop practical solutions to the problem. Rock, weld-wire mesh, and rockbolt samples exposed to corrosive and 
non-corrosive environments were provided by Greens Creek personnel, while Dywidag Systems International (DSI) supplied new weld-wire mesh and rockbolt samples for use in this study. SMRD researchers travelled to the Greens Creek mine to collect samples and conduct field studies. This paper summarises the preliminary results achieved in the first year of the project.

\section{$2 \quad$ Background}

\subsection{Initial field study}

SMRD researchers visited the Greens Creek mine in September 2015, to conduct preliminary visual surveys. Surveys indicated that mineralogy could be significant to the corrosive mechanism. Hassell et al. (2004) reported that mineralogy does not influence the corrosivity of a mine environment except in the case of sulphide mineralogy. The Greens Creek mine is composed of a polymetallic massive sulphide deposit, containing silver with significant by-products of zinc, gold, and lead. Mineralisation occurs discontinuously along the contact between a structural hanging wall (quartz mica carbonate phyllites) and footwall (graphitic and calcareous argillite). Major sulphide minerals (pyrite, sphalerite, galena, and tetrahedrite/tennantite) are present in the Greens Creek mine deposit. The high rate of corrosion is most apparent in ground support in contact with the dark-coloured graphitic argillite footwall rock.

The corrosion observed in the mine is characteristic of galvanic corrosion. Galvanic corrosion involves oxidation of an anode and reduction of a cathode, driven by differences in potential with a medium for ion transport (typically moisture). The half-cell reactions of galvanic corrosion of iron are listed in Equations (1) and (2).

$$
\begin{aligned}
& \mathrm{Fe}_{(\mathrm{s})} \rightarrow \mathrm{Fe}^{2+}{ }_{(\mathrm{aq})}+2 \mathrm{e}^{-} \\
& 2 \mathrm{H}^{+}{ }_{(\mathrm{aq})}+2 \mathrm{e}^{-} \rightarrow \mathrm{H}_{2(\mathrm{~g})}
\end{aligned}
$$

Galvanic corrosion also occurs when two metals are in direct contact (NACE 2012), where the more electronegative metal becomes anodic while the more electropositive metal becomes cathodic. This scenario has been observed at the Greens Creek mine where the rock support is in direct contact with the more electropositive dark argillite rock mass (Figure 1). The ground support acts as the anode while the rock mass acts as the cathode, representing the combination of 'rusted carbon steel' and 'carbon, graphite' in Table 1. Oxidation has effectively dissolved the support in these locations, necessitating a rehabilitation plan to replace any ground control found to be ineffective or highly corroded.

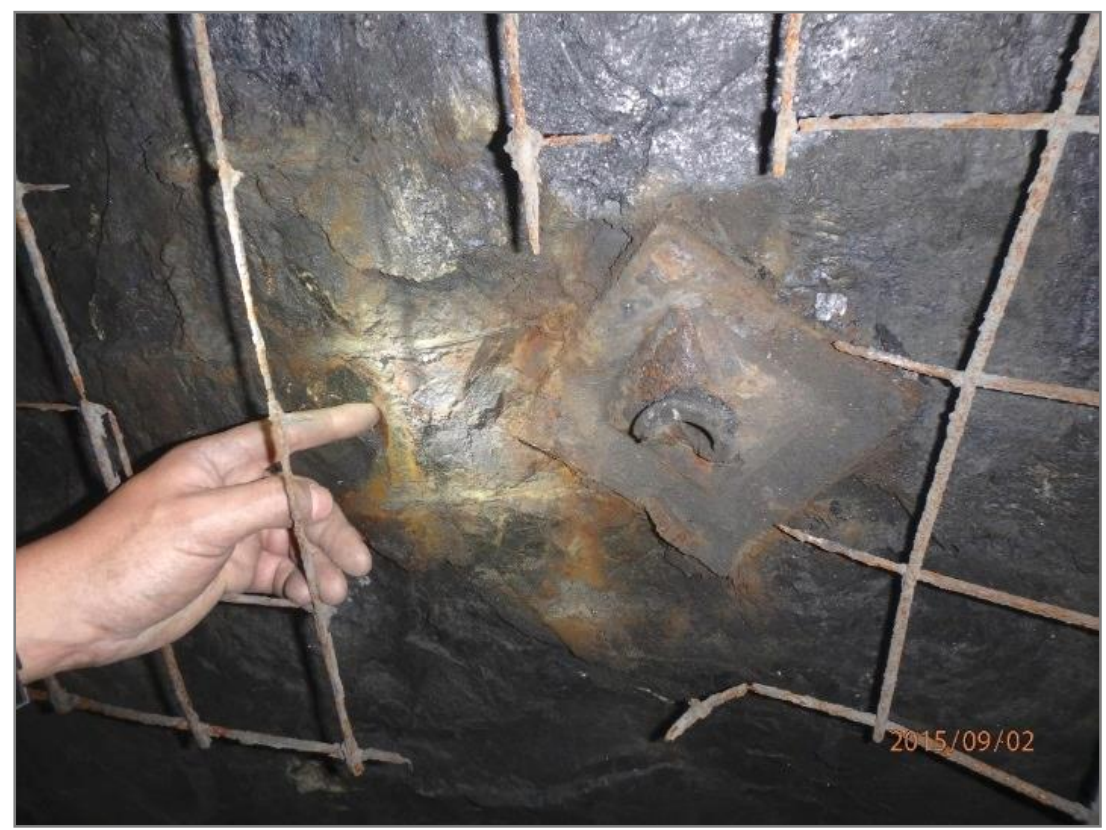

Figure 1 Galvanic corrosion of welded wire mesh in contact with dark graphitic argillite 
Table 1 Galvanic series from NACE (2012); when metals are in contact the difference in potential drives corrosion of the more electronegative metal

\begin{tabular}{|c|c|}
\hline Metal & Volts versus $\mathrm{Cu}-\mathrm{CuSO}_{4}$ \\
\hline \multicolumn{2}{|l|}{ Active or anodic end } \\
\hline Zinc & -1.10 \\
\hline Clean carbon steel & -0.50 to -0.80 \\
\hline Rusted carbon steel & -0.20 to -0.50 \\
\hline Carbon, graphite & +0.30 \\
\hline Nobel or cathodic end & \\
\hline
\end{tabular}

Heavy corrosion was found on the outside surface of galvanised friction rockbolts and polymer-coated Omega rockbolts extracted by over-core drilling (Figure 2). Scratching was noted on galvanised friction rockbolts as well as polymer-coated Omega bolts. Scratching of the bolt appeared to be a key starting point for pitting corrosion in Omega bolts. Scratching of galvanised friction rockbolts also led to general and pitting corrosion, however, there were scratches noted where corrosion had not yet occurred. This could be due to the galvanising process yielding protection deeper into the metal while a polymer-coating only protects the surface of the metal. The inside surfaces of the galvanised friction rockbolts show almost no corrosion, supporting the hypothesis that an outside influence, such as the rock mass, is attacking the bolts. Pitting observed in the bolt samples could be due to microbial influenced corrosion (MIC) playing a part in corrosion (Mattsson 1989). These early observations defined the specific research topics for SMRD researchers and the Hecla Mining Company.

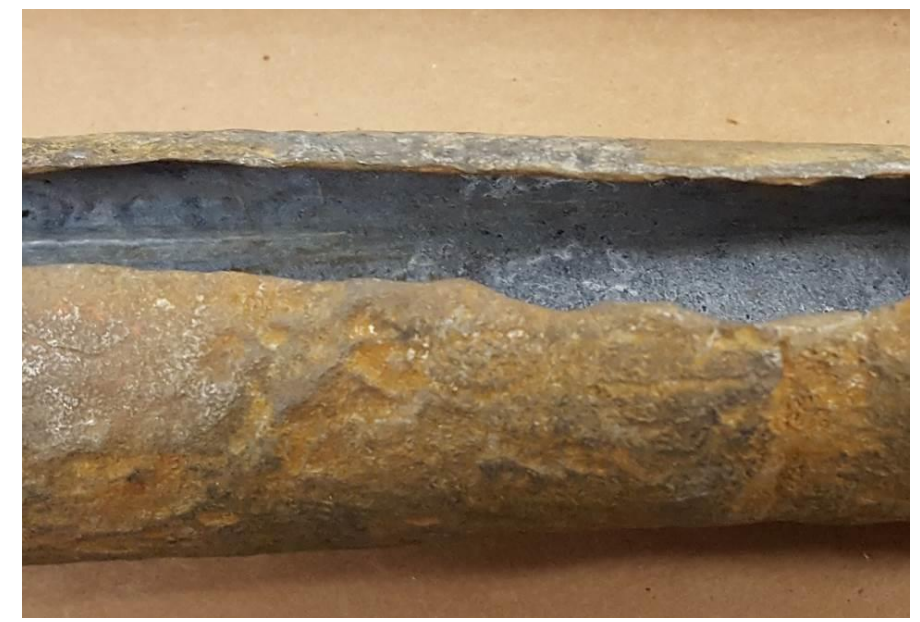

Figure 2 Friction rockbolt displaying heavy corrosion on the outside with very little corrosion in the interior, suggesting that corrosion is caused by outside influences such as the rock mass

\section{Methodology}

\subsection{Site selection}

To investigate the hypotheses established during the initial site visit in September 2015, three characteristic areas of the mine were selected for study by mine personnel and SMRD researchers. These areas, identified by visual survey, represented 'high corrosion', 'moderate corrosion', and 'low corrosion'. All study areas were scrutinised for any key components that may have effects on corrosion, including rock mass conductivity, atmospheric conditions, rock mass rating (RMR) characteristics, and ground support histories. The moisture content of the rock will be measured as the research continues; this is particularly important as moisture is known to affect conductivity. 
Atmospheric conditions at high-corrosion site $\mathrm{M} 390$, a large ventilation and exploration drift, were measured at $24^{\circ} \mathrm{C}$ with $77.8 \%$ humidity. RMR ranged from approximately 35 to 45 , but joint spacing generally $(<50 \mathrm{~mm})$ and condition (slightly rough and hard) were noted, along with minimal, but present groundwater. The site is located $120 \mathrm{~m}$ below sea level. The original rib bolts were $1.8 \mathrm{~m}$ long galvanised steel friction and Omega bolts, with $2.4 \mathrm{~m}$ long galvanised friction bolts in the back. The original bolting pattern was $1.2 \times 1.2$ $\mathrm{m}$, with slight overbolting, and $5 \mathrm{~mm}$ galvanised weld-wire mesh. Between the December 2015 and May 2016 visits, the area was rehabilitated with $5 \mathrm{~mm}$ polymer coated welded wire mesh and $1.8 \mathrm{~m}$ and $2.4 \mathrm{~m}$ coated friction and Omega rockbolts. This site also featured a visible boundary between corroded and non-corroded material, represented by the right-pointing arrow in Figure 3.

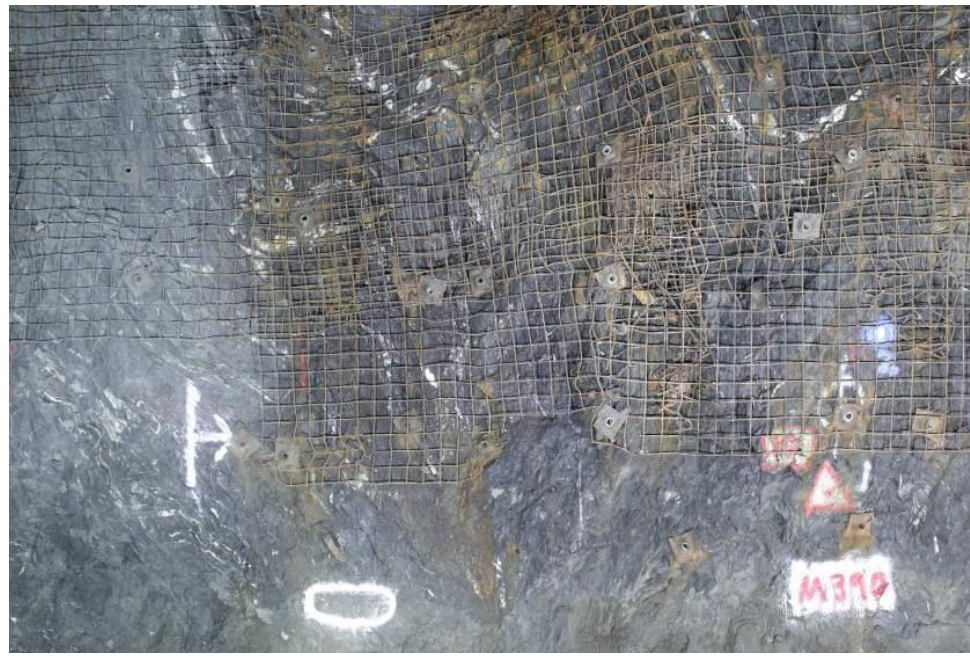

Figure 3 M 390 represents an area with high visual corrosion in dark argillite rock mass

Another heading called the $29 \mathrm{~L}$ represented the moderate corrosion location (Figure 4). The argillite rock mass was slightly red in colour, with pyrite visible. The site is located near the top of the mine, $412 \mathrm{~m}$ above sea level. The air temperature was $17.2^{\circ} \mathrm{C}$, and at $89.2 \%$ humidity, this was the most humid site studied. Water was noted in puddles in the road but not seeping through the rock mass. RMR ranged from 35 to 45. Support characteristics were similar to M 390, though rehabilitation was not deemed necessary.

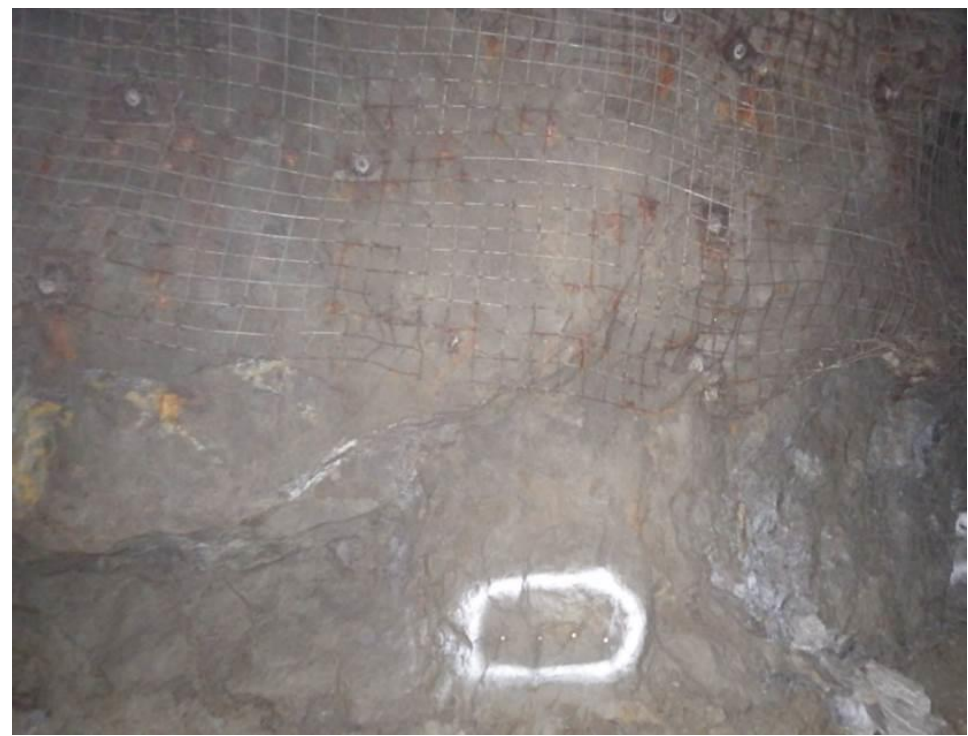

Figure $4 \quad 29 \mathrm{~L}$ represents an area with moderate visual corrosion in light red argillite rock mass

Raise access PD 2853 represented the low corrosion area (Figure 5). PD 2853 was observed to be dry, with light grey coloured phyllite. The air temperature was $13.2^{\circ} \mathrm{C}$ with $77 \%$ humidity, at an elevation of $140 \mathrm{~m}$ above sea level. RMR ranged from approximately 45 to 56 , joint spacing and condition were noted to be 
similar to those at $M 390$. The ground support consists of $1.8 \mathrm{~m}$ long galvanised friction rockbolts with a slightly overbolted $1.2 \times 1.2 \mathrm{~m}$ pattern and $5 \mathrm{~mm}$ welded wire mesh. No rehabilitation has been necessary up to this time. Overall, this site was in near original condition, with essentially no evidence of support corrosion. Together with sites M 390 and 29 L, three distinct levels of corrosion could be studied by SMRD researchers and Hecla Mining Company.

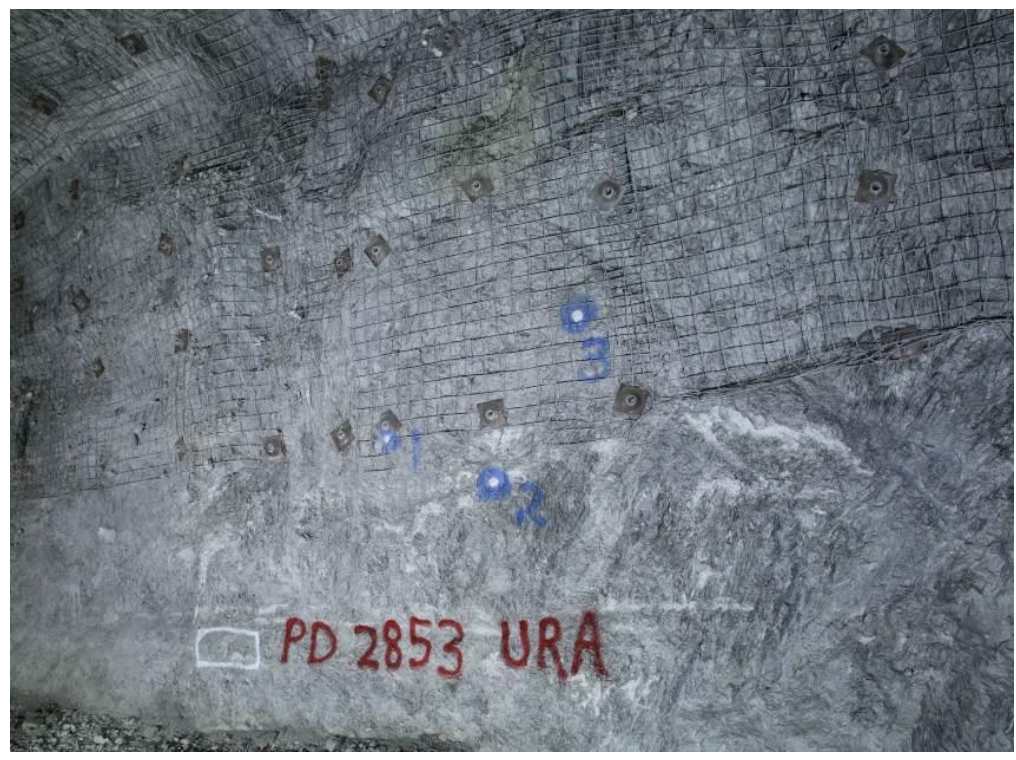

Figure 5 PD 2853 URA represents an area with low visual corrosion in phyllite rock mass

\subsection{Rock mass conductivity}

Two sets of rock mass conductivity measurements (December 2015 and May 2016) have been conducted at each of the three sites to investigate the role of rock mass conductivity on the corrosion of ground support. Conductivity is influenced by natural potentials, also called self-potential, which are caused by electrochemical or mechanical activity that occur in the subsurface of the earth. These low voltage electrical potentials may be caused by a variety of phenomena including weathering of sulphide mineral bodies, variation in rock mineralogy, and corrosion of manmade structures in the earth (Telford et al. 1990). Minerals capable of producing these electrical potentials include chalcopyrite, chalcocite, covellite, graphite, and anthracite, all of which are good conductors (Sato \& Mooney 1960). Previous research has concluded that greater conductivity correlates to higher corrosion (Peabody 2001; Polder 2009).

To determine the rock mass conductivity and its possible correlation with corrosion, measurements were taken using a small-scale Wenner array (ASTM International 2005). The Wenner array (Figure 6), consists of four equally spaced in-line electrodes. Nodes $C_{1}$ and $C_{2}$ are the current electrodes, while nodes $P_{1}$ and $P_{2}$ are potential electrodes. The spacing of the electrodes determines how far the current will penetrate, with larger spacing achieving greater depth and volume of earth. The bulk average resistivity is calculated by measuring the difference of the potential electrodes when a low frequency alternating current is passed into the rock through the current electrodes. The resistivity is calculated with Equation (3). The conductivity is the inverse of resistivity.

$$
R=2 \pi a(V / I)
$$

where:

$$
\begin{aligned}
\mathrm{R} & =\text { resistivity }(\Omega \mathrm{mm}) . \\
\mathrm{a} & =\text { electrode spacing }(\mathrm{mm}) . \\
\mathrm{V} & =\text { measured voltage }(\mathrm{V}) . \\
\mathrm{I} & =\text { current (ampere). }
\end{aligned}
$$




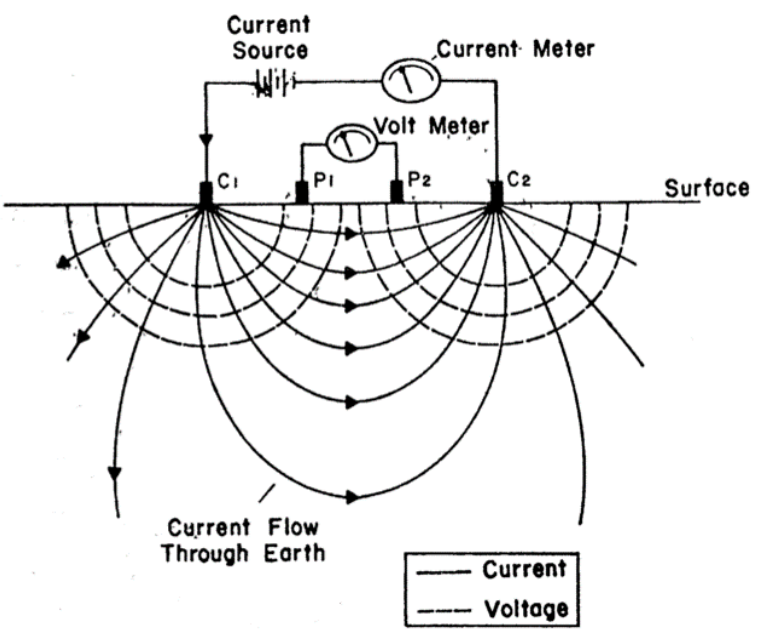

Figure 6 A Wenner array was used to measure the conductivity of the rock mass (ASTM 2005)

The electrodes were installed at the pre-selected sites in the ribs of excavation by drilling four holes $10.16 \mathrm{~cm}$ apart (Figure 7) and inserting $7.62 \mathrm{~cm}$ stainless steel construction screws as electrodes. With the electrodes in place, an instrument designed by SMRD researchers (Figure 8) was used to measure the current and voltage. These values were recorded and used to calculate the conductivity of the rock mass in each of the three areas.

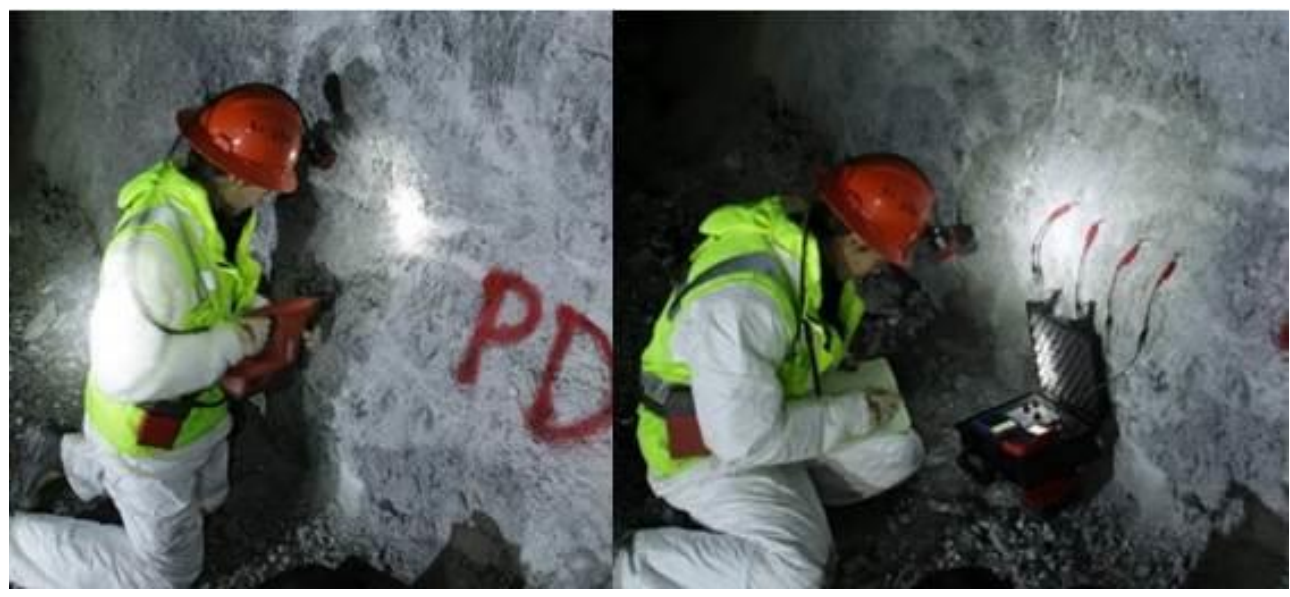

(a)

(b)

Figure 7 (a) Drilling holes for electrode insertion; and, (b) measuring the current and voltage used to calculate conductivity of the rock mass

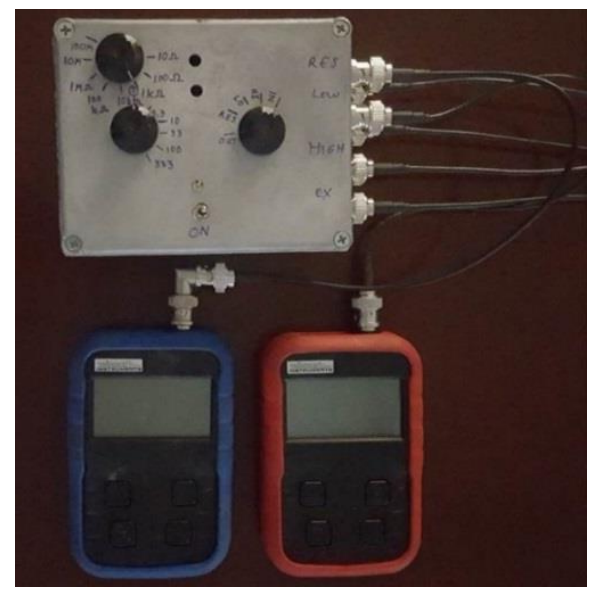

Figure 8 Instrument for measuring current and voltage 
The conductivity of rock samples was measured following the procedure described by Telford et al. (1990); the principles are the same as the Werner method. Rock samples were first cut to give flat edges for good connectivity with the current electrodes. Current was applied through conductive foam held tight to the ends of the sample with a rubber C-clamp, and $3.175 \mathrm{~mm}$ thick copper tape made contact with all faces as potential electrodes (Figure 9). The same instrument used to measure rock mass conductivity in the mine was used to measure rock sample conductivity.

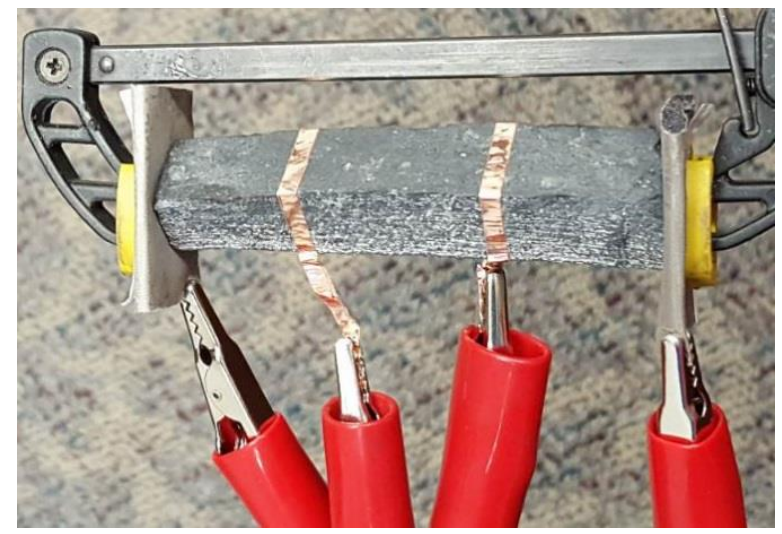

Figure 9 Rock sample conductivity measurement using conductive foam as current electrodes and copper tape as potential electrodes

The difference in potential was also measured between the rock and the mesh in the three study areas of the mine. Electrochemical reactions take place when there is a large potential difference of two materials in contact, and measuring this potential could indicate if the risk of aggressive corrosion is present. A voltmeter was connected to the wire mesh and the screws used as electrodes in the conductivity measurements; this provided good contact with the rock. The potential difference was measured in millivolts in each area. In the M 390 area, the difference in potential was measured on both sides of the boundary marking the transition to aggressive support corrosion.

The collection of data regarding rock mass conductivity, site atmospheric conditions, rock mass characteristics, and support histories constitutes much of the SMRD investigation into support corrosion at the Greens Creek mine thus far. A final component included laboratory investigation into organic triggers of corrosion.

\subsection{Microbial influenced corrosion}

The presence of bacteria and other microorganisms may greatly increase the rate of corrosion through MIC. Holman et al. (2010), King (1995) and White et al. (1996) report that MIC is usually part of a complex process involving surface fouling with deposits and scales, and differences in potential resulting from metallurgical variations in the metal surface. Non-uniform or patchy colonisation by microbial biofilms causes formation of differential aeration cells. The areas under these respiring colonies are depleted of oxygen relative to surrounding colonised areas leading to potential differences and, consequently, to corrosion (Maluckov 2012; Videla \& Herrera 2005). Antony et al. (2008) found that the alloying elements of stainless steels influence the rate of biofilm formation. Higher nickel and nitrogen content enhanced attachment of bacteria thereby causing pitting corrosion.

SMRD researchers sought to identify MIC in Greens Creek ground support samples by determining the presence of sulphate reducing bacteria (SRB). Maluckov (2012) demonstrated that the presence of multiple strains of bacteria, specifically those able to reduce sulphate $\left(\mathrm{SO}_{4}{ }^{2-}\right)$ to hydrogen sulphide $\left(\mathrm{H}_{2} \mathrm{~S}\right)$, led to increased levels of corrosion. These SRB are the most common bacteria to affect metal surfaces. The hydrogen sulphate product reacts with metal ions to form metal sulphides, accelerating the corrosion process already taking place (Javaherdashti 2011; Muyzer \& Stams 2008). It is important to note that the presence of SRB on a metal surface does not prove their involvement in the rate of corrosion (Beech 2003; Ontiveros-Valencia 2012). However, the possibility of SRB's acceleration of corrosion warrant investigation. 
In May 2016, samples of a bright yellow, wet, clumpy corrosion product were taken from the 627 access of the Greens Creek mine. These samples were analysed with weld-wire mesh samples to determine the presence of MIC. Three analytical tools were utilised: scanning electron microscopy (SEM), energy dispersive spectrometry (EDS), and Fourier transform infrared spectrometry (FTIR). Because the corrosion associated with SRB is localised and appears in patches, SEM was used to evaluate corrosion sites on the wire mesh as in previous work (Beech 2003; Maluckov 2012). EDS enhanced the SEM evaluation by providing data regarding the elemental makeup of the corrosion product, with sulphur being of particular interest. Fresh steel with no exposure to the mine was filed into flakes and then analysed with the corrosion product using a Hitachi TM-3030 tabletop SEM combined with EDS.

After SEM and EDS analysis, FTIR analysis was used to determine the presence of sulphate-reducing bacteria by detecting the presence of sulphate and iron sulphite ions (Rubio et al. 2006). Samples were dried in a desiccator for 24 hours and then formed into potassium bromide $(\mathrm{KBr})$ pellets; this is the standard practice outlined by the press manufacturer (International Crystal Laboratories 2000). KBr pellets were prepared by first grinding approximately $100 \mathrm{mg}$ of sample by hand using an agate mortar and pestle, followed by grinding for varying times using a miniature ball mill ('Wig-L-bug', Dentsply Rinn). Once ground, the sample was mixed with enough $\mathrm{KBr}$ powder to create a 100:1 $\mathrm{KBr}$-to-sample ratio. The mixture was pressed into a pellet using a hydraulic press ('E-Z Press', International Crystal Laboratories). After pulling a vacuum on the sample for one minute, approximately $5.44 \mathrm{t}$ of pressure was applied to the sample for two minutes. The pellet was removed from the press and inserted into the Bruker alpha-FTIR for analysis. All spectra were recorded between 4,000 and $500 \mathrm{~cm}^{-1}$ on a Bruker ALPHA FTIR Spectrometer in transmission mode. FTIR spectra interpretation was enhanced by using baseline correction and normalisation, as well as resolution enhancements including self-deconvolution (Choe et al. 2010; Griffiths \& De Haseth 2007; Mariey et al. 2001; Naumann et al. 1991). Self-deconvolution was performed on each spectrum by manually selecting the Lorentzian function and then reducing FWHH (full width of the peak at half-height) while increasing noise(Griffiths and De Haseth 2007).

Laboratory analysis of MIC, combined with field investigations of rock mass conductivity, atmospheric conditions, rock mass properties, and ground control histories represent the significant effort of SMRD researchers and Hecla Mining personnel in understanding the corrosion of ground support at the Greens Creek mine. The results of this preliminary work will be used to direct future research into this mechanism of ground control failure.

\section{$4 \quad$ Results}

\subsection{Rock mass conductivity}

Rock mass conductivity data from field investigations at the Greens Creek mine indicate that rock with higher conductivity is facilitating higher levels of corrosion. It has previously been noted that soil conductivities greater than $1.0 \times 10^{-4}(\Omega \mathrm{mm})^{-1}$ are considered highly corrosive (Peabody 2001). Figure 10 outlines how the lowest conductivity recorded exceeds this threshold. The circles on the graph correlate to the measurements taken in December 2015, while the triangles indicate the measurements taken in May 2016. Moderate corrosion data was measured at the $29 \mathrm{~L}$ site and two of the low corrosion data were measured at PD 2853. All other data was measured at M 390 as indicated in Figure 10. 


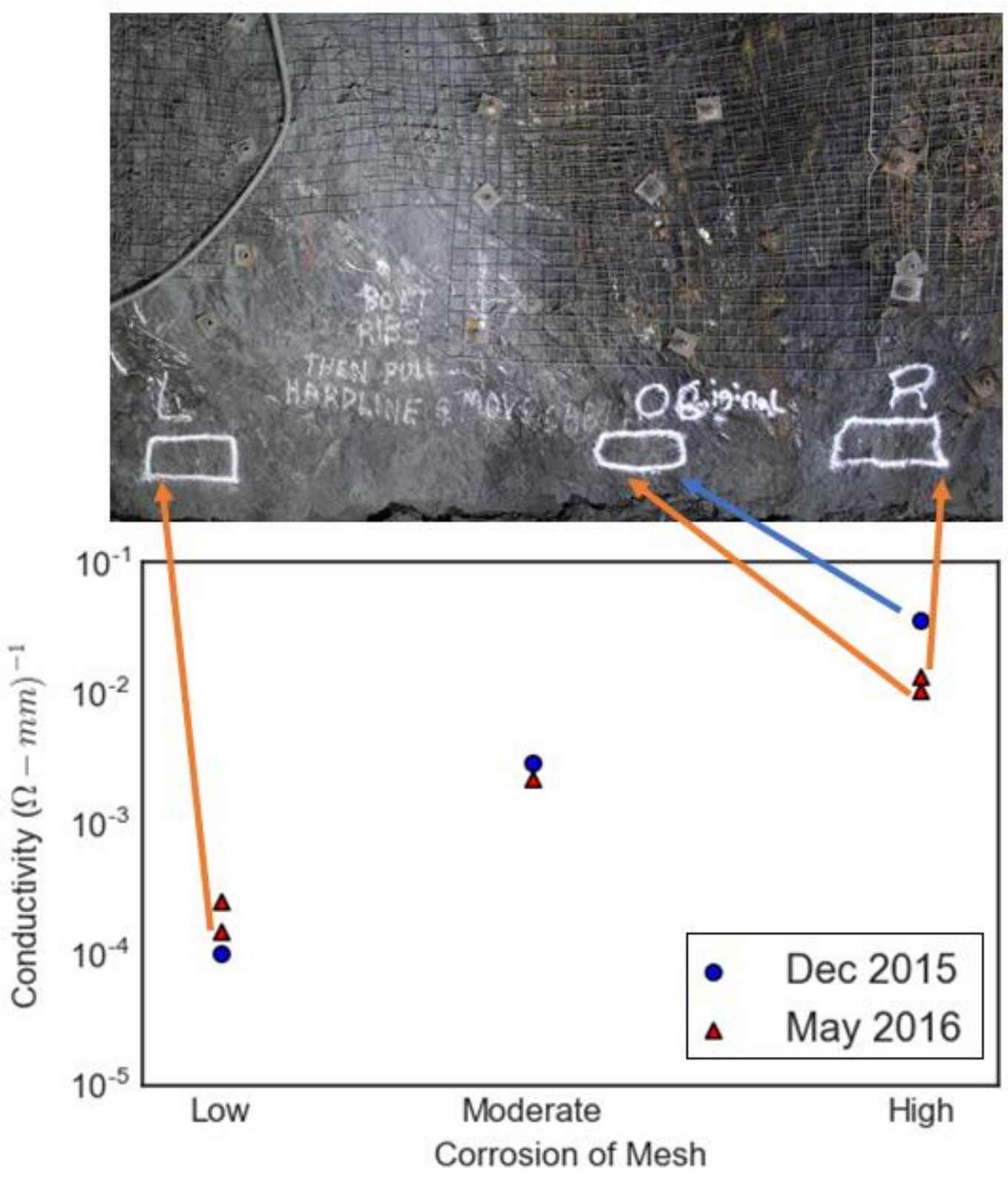

Figure 10 Conductivity measurements of rock mass and support at the Greens Creek mine. Moderate data was measured at the $29 \mathrm{~L}$ site, two of the low corrosion data were measured at PD 2853, and all other data was measured at M 390 as indicated

The measured conductivity of rock samples was correlated to the corrosion rate calculated from corresponding weld-wire mesh samples (Figure 11). There is a lot of variability in the data, this may be improved by making more rock sample conductivity measurements or by using more uniform samples such as diamond drill core samples. Carmichael (1982) suggests that for greater accuracy electrical properties should be measured in the rock mass rather than samples because of the strong dependence on environmental factors such as moisture content, temperature and vapour pressure. 


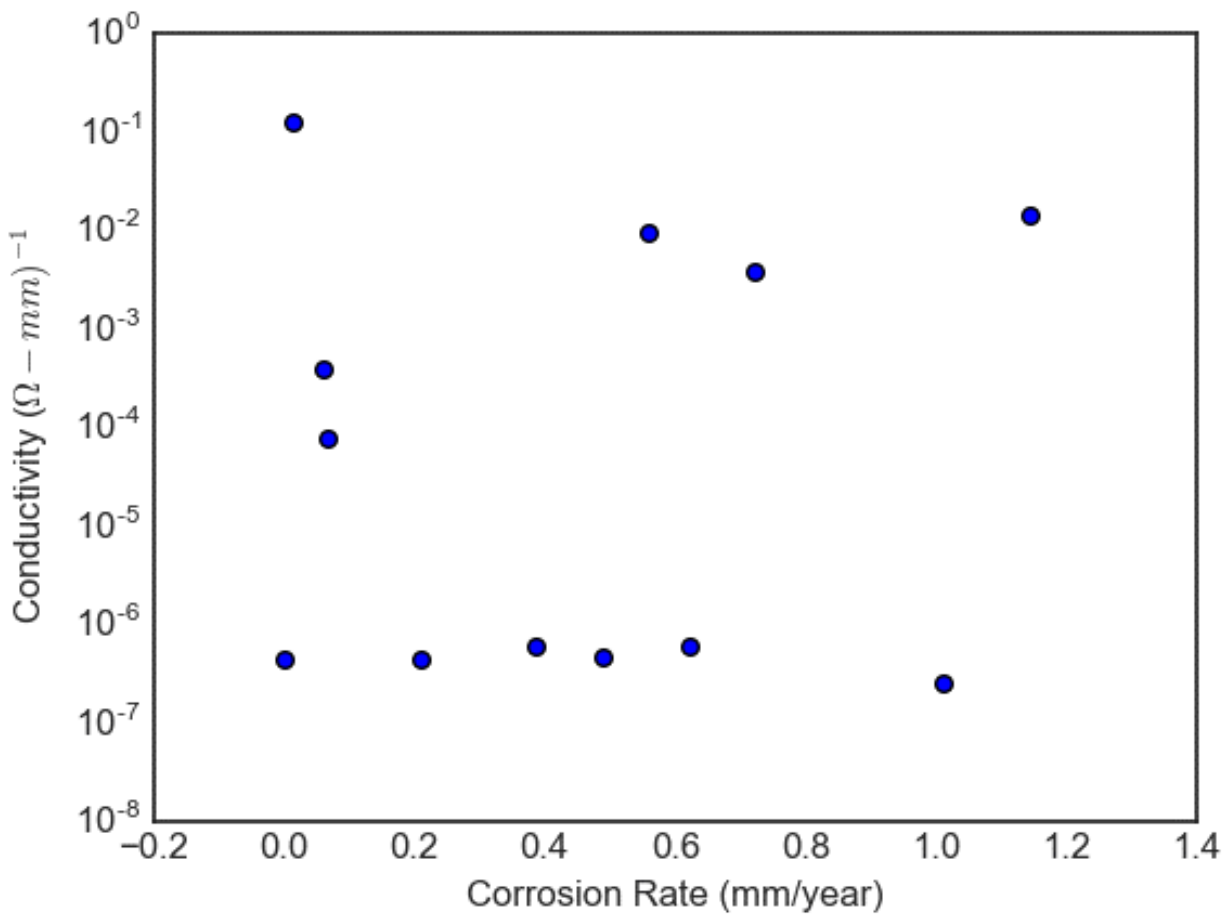

Figure 11 Corrosion rate of weld-wire mesh samples versus conductivity of corresponding rock samples

Voltage measurements between the rock mass and welded wire mesh followed a pattern similar to the rock conductivity data, except in the case of the low corrosion area of M 390 (Figure 12). Nonetheless, the difference in potential is still closer to the $29 \mathrm{~L}$ (mid-level corrosion) rather than the PD 2853 (low-corrosion) area. This unexpected result could be due to stray currents in the mesh matrix or differences in the rock type.

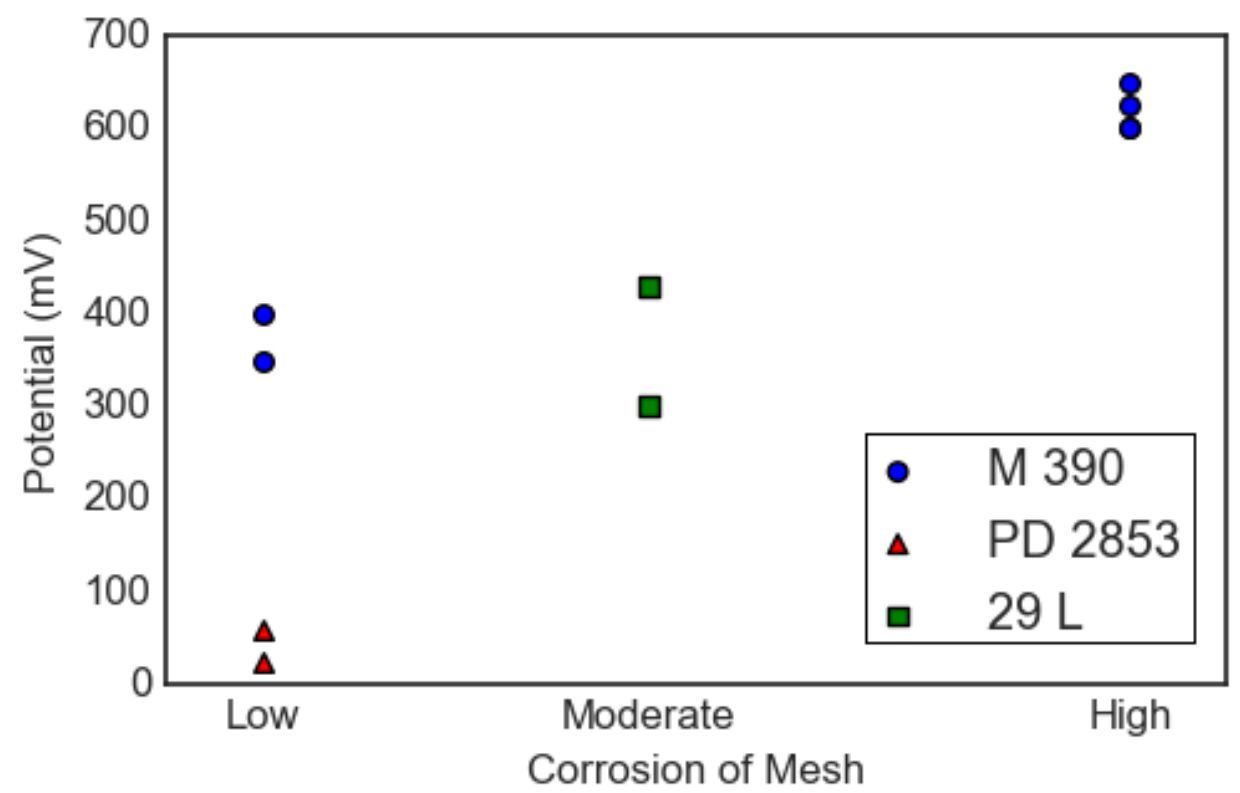

Figure 12 Difference in potential measured between the rock mass and the wire mesh correlate to amount of corrosion, except in the low corrosion area very close to the high corrosion area (M 390)

Atmospheric measurements indicated that these conditions are not the main driver for corrosion (Table 2). This is evident at M 390, where significantly different levels of corrosion are present despite the same atmospheric conditions. The same may be concluded regarding joint condition and support history. This indicates that in this case the electrochemical properties of the rock have a greater effect on the corrosion than do the other conditions measured. 
Table 2 Atmospheric conditions, conductivity, and potential at three mine sites

\begin{tabular}{llllllll}
\hline Location & $\begin{array}{l}\text { Dew point } \\
{ }^{\circ} \mathbf{C}\end{array}$ & $\begin{array}{l}\text { Temp } \\
{ }^{\circ} \mathbf{C}\end{array}$ & $\begin{array}{l}\text { Wet bulb } \\
{ }^{\circ} \mathbf{C}\end{array}$ & $\begin{array}{l}\text { Humidity } \\
\%\end{array}$ & $\begin{array}{l}\text { Conductivity } \\
\left(\Omega^{*} \mathbf{m m}\right)^{-1}\end{array}$ & $\begin{array}{l}\text { Potential } \\
(\mathbf{m V})\end{array}$ & Corrosion \\
\hline M 390 centre & 19.9 & 24.0 & 20.4 & 77.8 & $1.34 \cdot 10^{-2}$ & $600-625$ & High \\
M 390 right & 19.9 & 24.0 & 20.4 & 77.8 & $1.07 \cdot 10^{-2}$ & $600-650$ & High \\
M 390 left & 19.9 & 24.0 & 20.4 & 77.8 & $1.52 \cdot 10^{-4}$ & $350-400$ & Low \\
29 L & 17.2 & 19.1 & 17.5 & 89.2 & $2.21 \cdot 10^{-3}$ & $300-430$ & Moderate \\
\hline PD 2853 & 13.2 & 17.2 & 15.0 & 77.0 & $2.58 \cdot 10^{-4}$ & $25-60$ & Low \\
\hline
\end{tabular}

\subsection{Microbial influenced corrosion}

Pitting corrosion found on rockbolts retrieved from the Greens Creek mine (Figure 13) may be characteristic of the contribution of MIC to accelerated corrosion, chloride ions (McCafferty 2010), or sulphide minerals creating localised acidic conditions (Hassell et al. 2004). Because pitting may be due to a variety of environmental conditions, further investigation is required to positively identify MIC. SEM and EDS analyses confirmed the presence of sulphur in the corrosion product separated from the highly corroded weld-wire mesh. Iron was found on the fresh steel surface, but only small amounts of sulphur. The high amount of sulphur in the corrosion product, when compared to the lack of sulphur found on the metal surface, may suggest SRB activity. The continued presence of iron found on the corrosion product could indicate the production of iron sulphide (Figure 14).

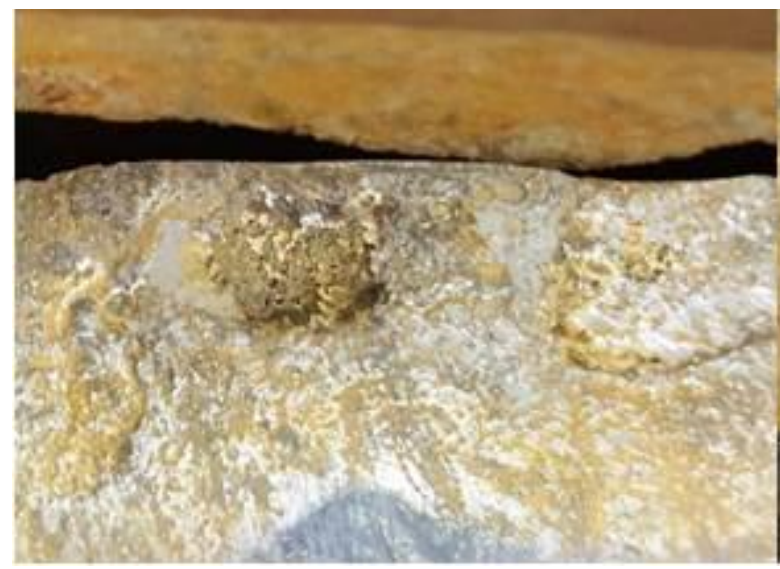

(a)

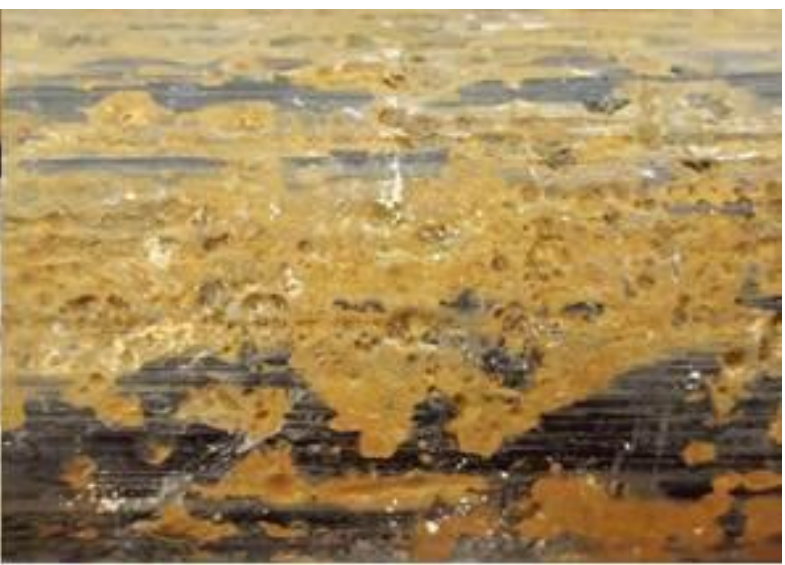

(b)

Figure 13 (a) Large pits in four year old friction bolt; and, (b) small pits on 10 month old coated Omega bolt

FTIR analysis may support the findings of the SEM and EDS analysis. While multiple aliquots of the corrosion precipitate sample were analysed on the FTIR, the spectra varied only in peak height, so only the spectrum representative of the average was selected for use in this paper. The peaks between 3,000 and $2,800 \mathrm{~cm}^{-1}$ indicate carbon hydrogen bonding $(\mathrm{C}-\mathrm{H})$, revealing the presence of a small amount of organic material, while the strength of the band in the spectra near $1,450 \mathrm{~cm}^{-1}$ indicates the presence of carbonate (Figure 12). The strong peaks seen in Figure 15 at $606 \mathrm{~cm}^{-1}$ and between 1,100 and $1,000 \mathrm{~cm}^{-1}$ are of particular interest in detecting sulphate and sulphite (Nakamoto 1997, in Rubio et al. 2006). The presence of carbonate, along with no detection of silicon, indicates that the broad band absorption between 1,000 and $1,100 \mathrm{~cm}^{-1}$ is potentially due to a sulphur oxygen bond (S-O) in sulphate or sulphite (Griffiths, personal communication, 10 July 2016). Regarding the spectra of weld-wire mesh flakes, the lack of strong peaks between 1,000 and $1,100 \mathrm{~cm}^{-1}$ and at $600 \mathrm{~cm}^{-1}$ indicates an absence of sulphur ions in the wire mesh that are present in the corrosion product. 


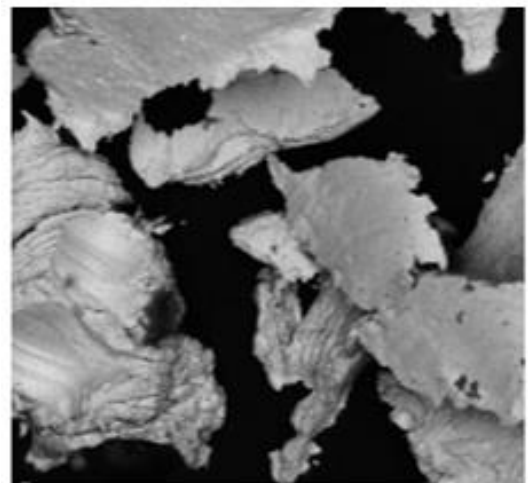

Mesh Flakes

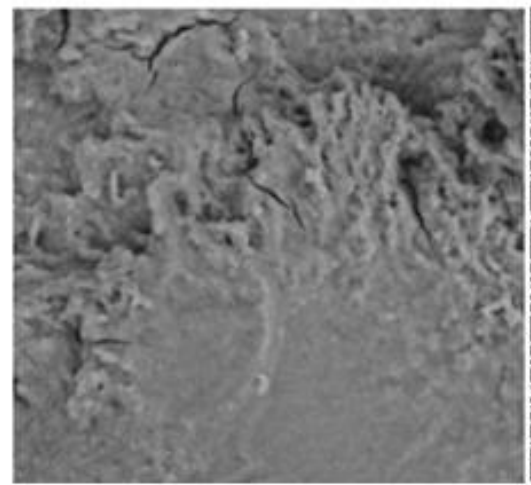

Corrosion Precipitate

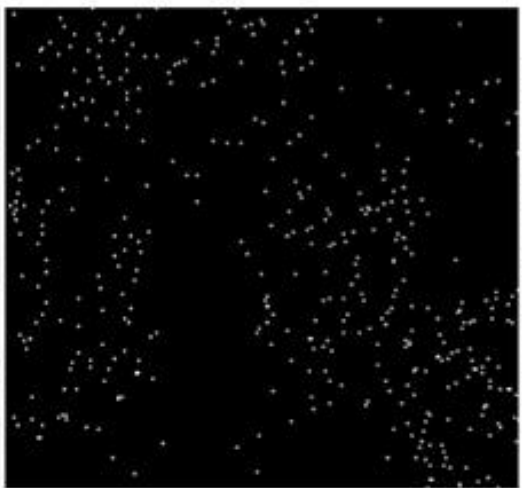

Sulphur

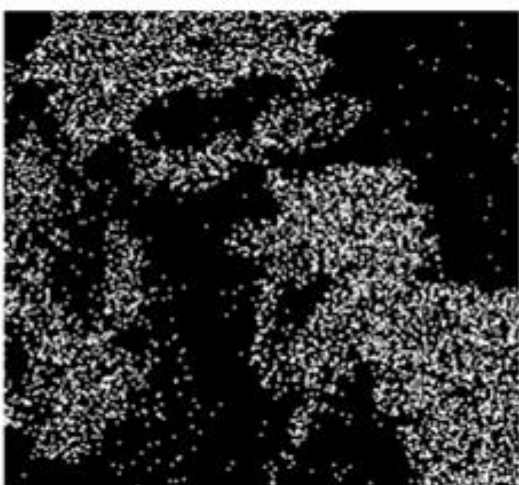

Iron

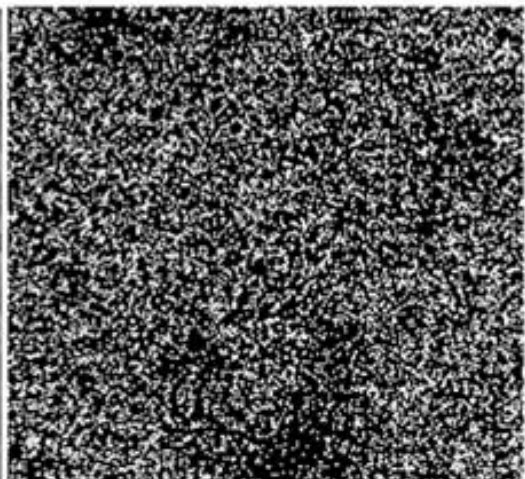

Sulphur

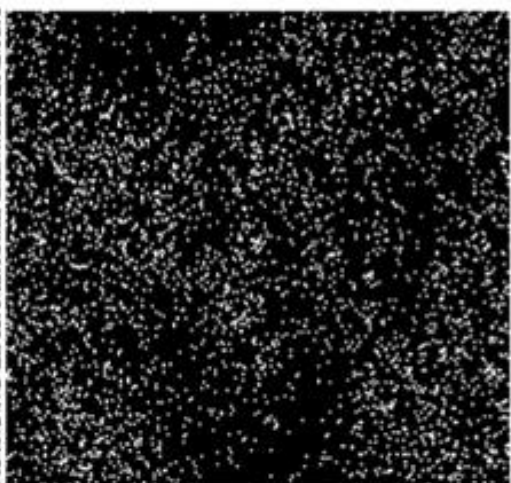

Iron

Figure 14 SEM and EDS images (each row is one sample) of the surfaces of flakes from a new wire mesh (top row); and corrosion precipitate (bottom row)

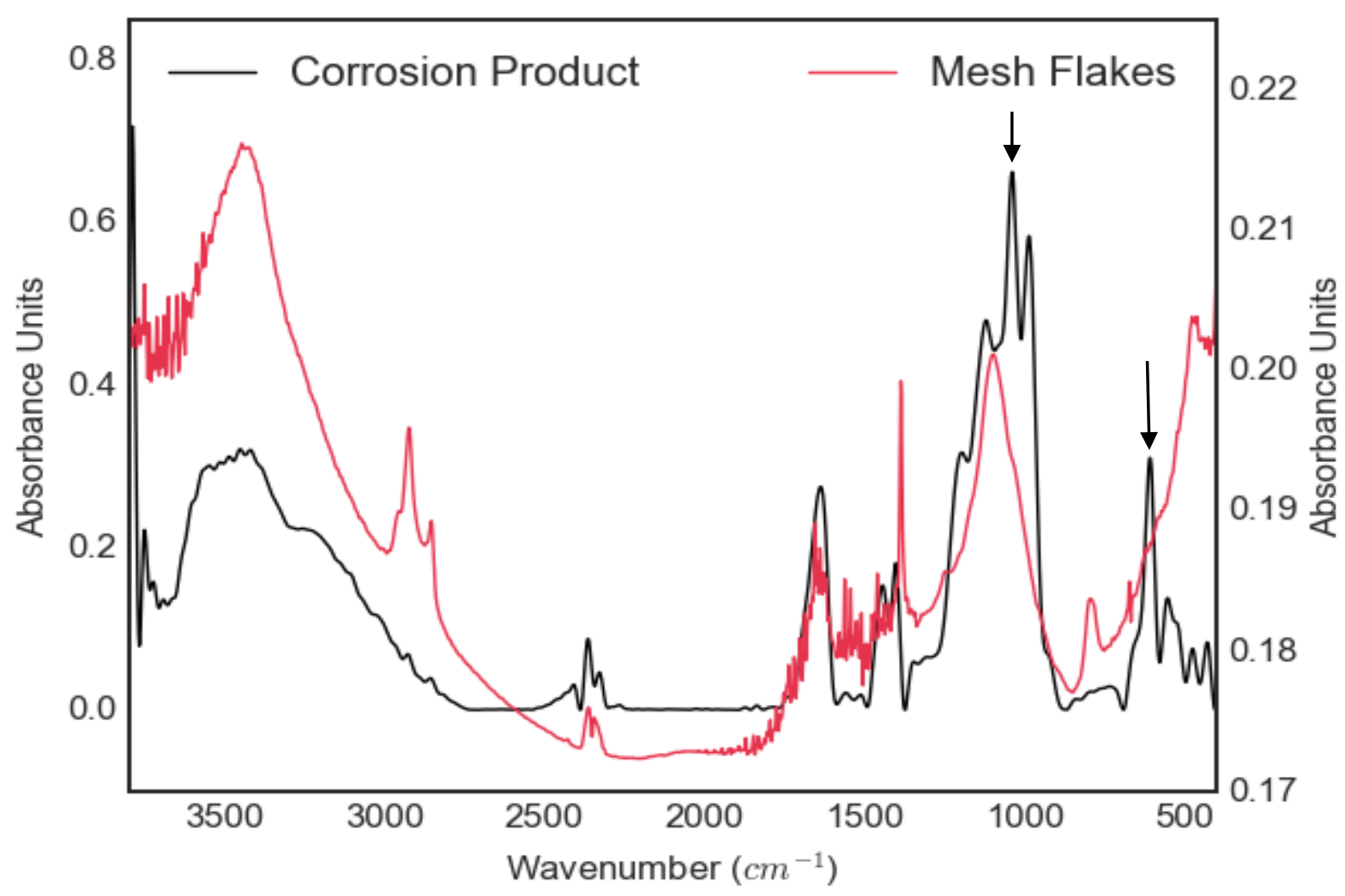

Figure 15 Average corrosion precipitate spectrum (left hand y axis) with wire mesh flakes spectrum (right hand $y$ axis); arrows indicate peaks at $600 \mathrm{~cm}^{-1}$ and between 1,100 and $1,000 \mathrm{~cm}^{-1}$ 
Taken together, SEM, EDS, and FTIR observations of corrosive product compared to non-corroded samples may indicate SRB activity in the 627 access of the Greens Creek mine. Therefore, it may be concluded that $\mathrm{MIC}$ is also occurring. Further investigation will determine whether this conclusion is correct, and if so, what corrective actions may be taken.

\section{Conclusion}

This preliminary study suggests that rock mass conductivity measurements could be used as a tool to understand the corrosive nature of a rock mass prior to installing ground support. When a rock mass is known to be conductive, extra protection such as coatings could be utilised to protect against aggressive corrosion. Surveys measuring the potential difference between the rock and the ground support may also be used to map how susceptible the ground support is to corrosion. Evidence suggests that electrochemical properties of the rock may be the primary drivers of support corrosion. Additionally, sulphate reducing bacteria may be present in the mine and, therefore, MIC could be contributing to the accelerated corrosion observed. Further research will clarify the conclusions of this paper.

\section{Acknowledgement}

Much of this research took place in the Greens Creek mine. The work and cooperation of the engineers is very much appreciated. SMRD would like to thank Mark Board for initiating this research project, DSI for providing weld-wire mesh and bolt samples, and Peter Griffiths for providing insight into spectra interpretation.

\section{Disclaimer}

The findings and conclusions in this report are those of the author(s) and do not necessarily represent the views of the National Institute for Occupational Safety and Health (NIOSH). Mention of any company or product does not constitute endorsement by NIOSH.

\section{References}

Antony, P, Raman, R, Kumar, P \& Raman, R 2008, 'Corrosion of 2205 duplex stainless steel weldment in chloride medium containing sulfate-reducing bacteria', Metallurgical and Materials Transactions A, vol. 39, no. 11, pp. 2689-2697.

ASTM International 2005, Standard Guide for Using the Direct Current Resistivity Method for Subsurface Investigation, ASTM International, West Conshohocken.

Beech, I 2003, 'Sulfate-reducing bacteria in biofilms on metallic materials and corrosion', Microbiology Today Magazine, Microbiology Society, London.

Carmichael, RS 1982, Handbook of Physical Properties of Rocks, CRC Press, Inc., Boca Raton.

Choe, E, Van Der Meer, F, Rossiter, D, Van Der Salm, C \& Kim, K-W 2010, 'An alternate method for Fourier transform infrared (FTIR) spectroscopic determination of soil nitrate using derivative analysis and sample treatments', Water, Air, and Soil Pollution Journal, vol. 206, no. 1-4, pp. 129-137.

Elias, E, Vandermaat, D, Craig, P, Chen, H, Crosky, A, Saydam, S, Hagan, P \& Hebblewhite, B 2013, 'Metallurgical examination of rockbolts failed in service due to stress corrosion cracking', in Y Potvin \& B Brady (eds), Proceedings of the Seventh International Symposium on Ground Support in Mining and Underground Construction, Australian Centre for Geomechanics, Perth, pp. 473-483.

Griffiths, P \& De Haseth, J 2007, Fourier Transform Infrared Spectrometry, John Wiley \& Sons, Inc, Hoboken, New Jersey.

Hassell, R, Villaescusa, E, Thompson, AG \& Kinsella, B 2004, 'Corrosion assessment of ground suppport systems', in Y Potvin \& E Villaescusa (eds), Ground Support in Mining and Underground Construction, Taylor \& Francis Group, London.

Holman, H-YN, Bechtel, HA, Hao, Z \& Martin, MC 2010, 'Synchrotron IR Spectromicroscopy: Chemistry of Living Cells', Analytical Chemistry Journal, vol. 82, no. 21, pp. 8757-8765.

Javaherdashti, R 2011, 'Impact of sulphate-reducing bacteria on the performance of engineering materials', Applied microbiology and Biotechnology Journal, vol. 91, no. 6, pp. 1507-1517.

King, RA 1995, 'Monitoring techniques for biologically induced corrosion', Bioextraction and Biodeterioration of Metals Journal, Cambridge University Press, New York.

International Crystal Laboratory 2000, 20 Ton E-Z Press KBr Pellet \& Lab Press Manual Rev. 03/22/00rdh, International Crystal Laboratory, Garfield, New Jersey.

Maluckov, BS 2012, 'Corrosion of steels induced by microorganisms', Metallurgical and Materials Engineering Journal, vol. 18, no. 3, pp. 223-231. 
Mariey, L, Signolle, J, Amiel, C \& Travert, J 2001, 'Discrimination, classification, identification of microorganisms using FTIR spectroscopy and chemometrics', Vibrational Spectroscopy Journal, vol. 26, no. 2, pp. 151-159.

Mattsson, E 1989, Basic Corrosion Technology for Scientists and Engineers, Ellis Horwood Publishers, West Sussex, England.

McCafferty, E 2010, Introduction to Corrosion Science, Springer, New York.

Muyzer, G \& Stams, AJM 2008, 'The ecology and biotechnology of sulphate-reducing bacteria', Nature Reviews Microbiology Journal, vol. 6, no. 6, pp. 441.

NACE 2012, Cathodic Protection Tester Course Manual, NACE International, Houston, Texas.

Nakamoto, K 1997, Infrared and Raman Spectra of Inorganic and Coordination Compounds, John Wiley \& Sons, Inc, New York.

Naumann, D, Helm, D, Labischinski, H \& Giesbrecht, P 1991, 'The characterization of microorganisms by fourier-transform infrared spectroscopy (FTIR), in N Wh (ed.), Modern Techniques for Rapid Microbiological Analysis Journal, Wiley-VCH, New York.

Ontiveros-Valencia, A, Ziv-El, M, Zhao, H, Feng, L, Rittmann, B \& Krajmalnik-Brown, R 2012, 'Interactions between nitrate-reducing and sulfate-reducing bacteria coexisting in a hydrogen-fed biofilm', Environmental science \& technology Journal, vol. 46, no. 20, pp. 11289-11298.

Peabody, AW 2001, Peabody's Control of Pipeline Corrosion, 2nd edn, NACE International, Houston, Texas.

Polder, RB 2009, 'Critical chloride for reinforced concrete and its relationship to concrete resistivity', Materials and Corrosion Journal, vol. 60, no. 8, pp. 8.

Rubio, C, Ott, C, Amiel, C, Dupont-Moral, I, Travert, J \& Mariey, L 2006, 'Sulfato/thiosulfato reducing bacteria characterization by FT-IR spectroscopy: a new approach to biocorrosion control', Journal of Microbiological Methods, vol. 64, no. 3, pp. 287-296.

Sato, M \& Mooney, HM 1960, 'The electrochemical mechanism of sulfide self-potentials', Geophysics Journal, vol. 25, no. 1, pp. 226-249.

Telford, WM, Geldart, LP \& Sheriff, RE 1990, Applied Geophysics, University of Cambridge, Cambridge.

Videla, HA \& Herrera, LK 2005, 'Microbiologically influenced corrosion: looking to the future', International Microbiology Journal, vol. 8, no. 3, pp. 169-180.

White, DC, Arrage, AA, Nivens, DE, Palmer, RJ, Rice, JF \& Sayler, GS 1996, ‘Biofilm ecology: On-line methods bring new insights into mic and microbial biofouling', Biofouling Journal, vol. 10, no. 1-3, pp. 3-16. 